DIGITALCOMMONS

— @WAYNESTATE -
Michigan Journal of Counseling:

Research, Theory and Practice

Volume 35 | Issue 2

Article 4

9-1-2008

\title{
An Examination of the Process, Outcomes and Attitudes of Counselor-Trainees Participating in an Experiential Group: An Exploratory Study
}

Jacqueline A. Conley

Chicago State University, jconley@csu.edu

Michael C. Edwards

Chicago State University

Follow this and additional works at: https://digitalcommons.wayne.edu/mijoc

\section{Recommended Citation}

Conley, J. A., \& Edwards, M. C. (2008). An Examination of the Process, Outcomes and Attitudes of Counselor-Trainees Participating in an Experiential Group: An Exploratory Study, Michigan Journal of Counseling, 35(2), 20-28. doi:10.22237/mijoc/1220227380

This Article is brought to you for free and open access by the Open Access Journals at DigitalCommons@WayneState. It has been accepted for inclusion in Michigan Journal of Counseling: Research, Theory and Practice by an authorized editor of DigitalCommons@WayneState. 


\section{An Examination of the Process, Outcomes and Attitudes of Counselor-} Trainees

\section{Participating in an} Experiential Group:

\section{An Exploratory Study}

Jacqueline A. Conley, Ph.D.

Chicago State University

Michael C. Edwards, Ed.D.

Chicago-State University

Contact the authors at:

Chicago State University

9501 S. Martin Luther King Jr. Drive,

Department of Psychology, HWH 328

Chicago, IL 60628.

Phone: 773-995-2317

Email: jconley@csu.edu

dr.j.a.conley@gmail.com

This exploratory study attempts to examine the impact of experiential group work training on counselor-trainees. Survey data about group process, attitudes and outcomes were gathered from 15 counselor-trainees who were enrolled in a group-counseling course and participated in an experiential group. Correlations revealed statistically significant relationships between pre-group process variables and post-group outcome and attitude variables. The non-parametric Wilcoxon Signed Rank Test indicated significant differences between pre-group and post-group measures for the group process. Implications for future research are presented.

Keywords: Experiential group, counselortrainees, group process, group work ccording to the Council for Accreditation of Counseling and Related Educational Programs (CACREP) 2001 Guidelines, Master's level programs are required to offer at least one course in group work. The Association for Specialists in Group Work (ASGW) 2000 Standards indicates that counselor trainees should participate in 10 clock hours of experiential training. These standards require that the experiential group provide counselor-trainees with the opportunity for skill development in appropriate self-disclosure, giving and receiving feedback, development of empathy, self-awareness, use of confrontation and experiencing group membership (Corey \& Corey, 2002; Johnson \& Johnson, 1997; Yalom, 1995). Brown (1992), Merta, Wolfgang, and McNeil (1993), and Robison, Jones, and Berglund (1996) stated that a comprehensive experience for trainees incorporates the following components: lecture, encouragement of critical thinking about the group process variables, and experiential learning. Thus it is expected that an effective group experience along with didactic training would lead to personal and professional growth and development of counselortrainees.

Research on group work is vast; however, limited research has focused on the experiential component of counselor-training. Researchers who have examined the experiential group experience have focused on the influence of techniques on the group process (McGuire, Taylor, Broome, Blau, \& Abbott, 1986); the use of corrective feedback (Stockton, Morran \& Harris, 1991); the use of student letter exchange (Cummings, 2001); the use of process notes (Falco \& Bauman, 2004); and activities for working with counselortrainees in experiential groups (Osborn, Danninhirsch, $\&$ Page, 2003). The aforementioned researchers noted the importance and the impact of the experiential group on counselor-trainees' personal and professional development.

Other researchers have examined attitudes and perceptions of counselor-trainees participating in experiential groups. For example, Irving and Williams (1995) examined perceptions about the group process, counselor training outcomes, and trainees' preferred learning styles. The learning styles were identified as activists, reflectors, theorists, and pragmatists. The researchers suggested that learning styles provided 
a gauge to understand how participants' might feel in a group. This knowledge will provide a basis for understanding group participants' individual needs and increase knowledge about those who might and might not benefit from the group experience.

Researchers have not extensively examined the impact of the experiential group on the group process, group outcomes, or attitudes among counselor-trainees. One such study by Anderson and Price (2001) assessed attitudes about the group experience of 108 counselortrainees enrolled in seven counseling programs. The researchers assessed trainees' perceptions of the effectiveness of the experiential group by examining self-reported attitudes about outcomes (the usefulness of the experiential group and whether the group was viewed as a positive learning experience), and group process (quality of the learning experience, issues of dual relationships or privacy concerns, general comfort with the group, and choice to participate in the experiential group). They concluded that counselortrainees believed the group experience was a vital part of their counselor training and that some discomfort in the group might be an unavoidable experience for some of the participants.

Perrone, Smith, and Carlson (2003) examined goal setting and attainment among 56 counselor-trainees who participated in an experiential group. A list of ten goals were delineated from the trainees' responses which included building self-awareness, personal growth, building group facilitation skills, understanding the group process, personal growth as a counselor, increased confidence and comfort with group work, building interpersonal skills, learning from role modeling, developing relationships, and experiencing people from diverse cultures and background. The researchers found that building self-awareness, personal growth, and group facilitation skills were the highest goals reported by counselor-trainees. The second highest goals reported included understanding the group process, developing empathy, and sensitivity for future group members.

\section{Purpose}

Based on the limited research that examined process, outcomes and attitudes, the current researchers decided to conduct this exploratory study. Additionally, Anderson and Price's (2001) study served as the foundation for the current study. The researchers; however, attempted to expand on Anderson and Prices' research by examining the relationships between the variables and examining for differences in pre and post group scores. The researchers operationally defined group process, outcomes, and attitudes. Process was defined as the ability to use the self in an experiential group (Corey \& Corey, 2002; Jacobs, Masson \& Harvill, 2002; Yalom, 1995). Outcome was defined as the effects an experiential group has on self-perception (Gladding, 2003). Attitude was defined as the overall feeling or reflection about the experiential group. Based on the experiential group literature and the researchers' experience with group facilitation and work with counselor-trainees the following hypotheses were developed: 1) There will be a significant relationship between the pre-group process and post-group outcomes; 2) There will be a significant relationship between pre-group process and post-group attitudes; and 3) There will be a significant difference between the process, outcome, and attitude variables on pre- and post-group measures.

\section{Method}

\section{Participants}

The participants included 15 master's-level counselor education students enrolled at a mid-size midwestern university. At the time of the data collection, the participants were enrolled in a theory and technique group counseling course and were participating in an experiential group component. Additionally, the participants were not enrolled and had not taken any clinical courses. The racial make-up included AfricanAmericans $(n=14,93.3 \%)$ and Caucasian Americans $(\mathrm{n}=1,6.6 \%)$. The gender breakdown included females $(n=14,93.3 \%)$ and males $(1,6.6 \%)$. The participants' ages were grouped as follows: $20-29(\mathrm{n}=5,33.3 \%)$; $30-39(\mathrm{n}=2,13.3 \%) ; 40-49(\mathrm{n}=6,40 \%)$; and 50$59 \mathrm{n}=2,13.3 \%)$. The participants' academic track included community counseling $(n=6,40 \%)$ and school counseling $(n=9,60 \%)$.

\section{Instrument}

For the purpose of this project, the researchers developed a 25-item questionnaire which consisted of three subscales that assessed the group process, outcomes, and attitudes variables. Based on the research and the researchers' experience, it was believed that these three variables were interrelated and provided an increased understanding of the experiential group experience (Donati \& Watts, 2005). 
The group process scale consisted of 15-items which were designed to elicit information on trust, disclosure, willingness to formulate specific goals, willingness to prepare for group, active participation, expression of feelings, listening to others, understanding others, resisting group pressure to do, resisting pressure to say things, giving/receiving feedback, monopolizing, genuineness, support, and confronting. An inter-item reliability analysis of the group process subscale was conducted and a Cronbach alpha coefficient of .77 was obtained.

The group outcome subscale consisted of 5-items which were partly based on items from Anderson and Price's (2001) questionnaire. The group outcome subscale was designed to elicit information on pressure to disclose, anxiety, concern about being evaluated, and level of difficulty. An inter-item reliability analysis of the group outcome subscale was conducted and a Cronbach alpha coefficient of .34 was obtained.

The attitude subscale consisted of 5-items which were developed to elicit information on choice, personal boundaries, level of comfort, and participation in the experiential group. An inter-item reliability analysis of the attitudinal subscale was conducted and a Cronbach alpha coefficient of .52 was obtained.

The Cronbach alphas of the outcome and attitude subscales, respectively .34 and .52 , were low due to the sample size and the small number of items ( 5 each as opposed to 15). An overall reliability analysis was conducted across all three subscales, which consisted of 25-items, and an overall Cronbach alpha coefficient of .80 was obtained for the entire questionnaire. Thus, the overall Cronbach alpha of .80 must be interpreted with extreme caution.

\section{Procedure}

The voluntary participants comprised counselortrainees who were enrolled in a group counseling course that included an experiential component. The counselor-trainees, at the time of participation, had not taken any of the clinical courses such as pre-practicum, practicum, or internship. The instructor for the course, who was one of the researchers, informed the students during the 3rd and 6th week of class about the project and that they would complete a survey during the first and last experiential group sessions. Additionally, the counselor-trainees were informed that participation in the research project was voluntary, confidentiality would be maintained, their responses would be anonymous, and participation or non-participation would not affect their grade. The experiential group was held in the counseling center and the facilitator was also one of the researchers. The focus of the 7-week time-limited group was to provide personal group counseling, skills development, and to experience the group process. The data collection was gathered during the first and last group sessions. Thus, during the first group session, the participants completed a consent form, demographic form, and the questionnaire. For seven weeks the counselor-trainees participated in the experiential group and during the seventh group session, the participants completed the questionnaire again. The project received the university's institutional review board approval.

\section{Results}

\section{Analyses}

First, the researchers conducted a correlation analysis to examine the relationship between the pre-group process variables and the post-group outcome variables and found that there was a relationship present (see Table 1). Three pre-group process variables were significantly correlated with the post-group outcome variable: "knowing how much personal information to disclose." Of these three significant correlations, "knowing how much personal information to disclose" negatively correlated $(\mathrm{r}=-.72, \mathrm{p}<.01)$ with "ability to give and receive feedback." Whereas, "knowing how much personal information to disclose" positively correlated with "group trust me" $(r=.60, p<.05)$ and "avoids storytelling" $(\mathrm{r}=.56, \mathrm{p}<.05)$.

Second, the researchers then examined the structure of the relationship between the pre-group process variables and the post-group attitude variables (see Table 2). The findings support the hypothesis about a relationship between the pre-group process variables and the post-group attitude variables. There was a positive correlation $(\mathrm{r}=.56, \mathrm{p}<.05)$ between "avoids storytelling" and "choice."

Finally, percentages for pre and post group participants' responses to the items measuring process, outcomes, and attitudes are presented in Table 3. It was hypothesized that a statistically significant difference existed among the process, outcome, and attitude variables on both pre- and post-group measures. Reported in Table 4 are the mean scores and standard deviations for the pre/post group process variable. A series of Wilcoxon Signed Ranks Tests were used and significant differences existed between pre and posttest 
measures for 12 of the 15 group process items and Table 5 presents theZ-values, $\mathrm{N}$-ties, and $\mathrm{p}$-values for the group process items that were statistically significant. The Wilcoxon Signed Rank Test was used because the data available for analysis in the small sample $(n=15)$ did not allow the researchers to establish normality nor could we assume normality on the variables' distribution in the population. Although the t-test is generally robust to violations of normal distribution, the researchers were also concerned about measurement issues. Without being able to assume equal intervals, the researchers would not be able to make statistically meaningful comparisons regarding means and standard deviations. The Wilcoxon Signed Rank Test, like the t-test, compares two related samples by testing the null hypothesis that the medians of two samples do not differ. Hence, the Wilcoxon Matched-Pairs Test does not rely on the estimation of population parameters like normality, means and standard deviations.

There were no significant pre and post-group differences for the group process items that measured "group trusts me", "listen to others", and "thinks about achieving goals." There were no significant pre and post-group differences for the group outcome or group attitude variables.

\section{Discussion}

A personal understanding of group process is essential to the counselor-trainees' personal and professional growth and development. CACREP Guidelines and the Association for Specialists in Group Work Standards support and recommend that counselortrainees participate in an experiential group. As a result of the experiential group component, counselortrainees can experience, first hand, the group process, skills acquisition and development and the ability to use self in a group. Additionally, the group facilitator or counselor educator gains an awareness of the counselor- trainees' experiences and attitudes about participating in the experiential group. Thus, this exploratory study was designed to gain a better understanding about the group process, outcomes and attitudes of counselortrainees; however, due to severallimitations the results must be interpreted with caution and the conclusions provided are speculative.

Group trust (process) and personal disclosure (outcome) were highly correlated, suggesting that facilitators should quickly establish the conditions for group trust for personally meaningful interaction to

occur. In our experience, groups that do not achieve a level of trust have difficulty moving through the process. Personal disclosure and feedback were also highly correlated, further suggesting the importance of the facilitator's ability to manage the process whereby giving/receiving feedback in lieu of personal disclosure is minimized. Group members "avoid story telling" (process), thereby representing being in the here and now of the process, was positively correlated with feeling like one had some choice about being in the group (attitude). This finding suggests that instructors/ facilitators exercise caution in the way the experiential group is initially explained or presented thus stressing the importance of the role of the here and now and its impact on the individual and group's development. Finally, significant differences between the pre-post group variables only existed for the group process 
variables. It is not clear what specific factors contributed to the change in the group process items. It is the researchers' belief that the change was impacted by the counselor-trainees participation in the group process. This assumption is based on the fact that the counselortrainees did not have exposure to any clinical course that might have provided them with the opportunity to engage in the process items (i.e., ready to trust in the group). Therefore, the researchers assume that the differences might be attributed to participation in and the effectiveness of the experiential group. A closer examination of these variables is warranted.

\section{Limitations and Suggestions for Future Research}

This exploratory study provided information about the group process, outcomes, and attitudes of counselortrainees; however, limitations existed. First and foremost, discussion about the instrument used to collect the data must be addressed. The instrument did not undergo the rigorous methodology requirements utilized in development of instruments. Instead, the researchers developed the instrument solely to gather exploratory data on relationships and differences between the variables at two points in time. The instrument did allow the researchers to answer questions about the experiential group and counselor-trainees' experiences and attitudes about the group process. Future studies should use a comprehensive instrument that contains more items per variable and validity and reliability testing.

Another limitation was the dual role of the researchers. One of the researchers was the group facilitator and data collector. These dual roles might have influenced the counselor-trainees' responses on the questionnaire. Although the counselor trainees were assured that their responses were anonymous the knowledge that the facilitator had access to the data is important to note. Therefore, at some level, the internal validity of the study might have impacted the results. Future studies need to address this limitation by having another person collect the data.

The data was collected on 15 participants therefore the power of the results and generalizability are limited. First the sample size was very small. Future studies need to overcome this limitation by increasing the sample size by collecting data over various semesters or broadening the data collection to multiple sites. Gender, age, ethnicity and level of graduate study were not examined; however, to broaden the scope of future studies a more diversified sample should be utilized.

Finally, a limitation existed in the design of the study whereby the researchers examined the differences between pre and post-group measures. The researchers did not use a control group therefore contributing to the limitations of any interpretations and conclusions being made about the findings. Thus, it is difficult to determine the true nature of the changes and future studies should include a control group. 


\section{References}

Anderson, R., \& Price, G. (2001). Experiential groups in counselor education: Students attitudes and instructor participation. Counselor Education and Supervision, 41, 111-120.

Association for Specialist in Group Work. (2000). Association for Specialists in Group Work: Professional standards for the training of group workers. Journal for Specialists in Group Work, 25, 327-342.

Brown, N. (1992). Teaching group dynamics: Process and practice. Westport, CT: Praeger.

Corey, M.S., \& Corey, G. (2002). Groups: Process and practice (6th.ed). Pacific Grove, CA: Brooks/Cole.

Council for Accreditation of Counseling and Related Educational Programs (2001). CACREP accreditation standards and procedure manual. Alexandria, VA.

Cummings, A.L. (2001). Teaching group process to counseling students through the exchange of journal letters. Journal for Specialists in Group Work, 26 (1), 7-16.

Donati, M., \& Watts, M. (2005). Personal development in counselor training: Towards a clarification of interrelated concepts. British Journal of Guidance and Counselling, 33 (4), 475-484.

Falco, L., \& Bauman, S. (2004). The use of process notes in the experiential component training of group workers. Journal for Specialists in Group Work, 29 (2), 185-192.

Gladding, S.T., (2003). Group work: A counseling specialty (3rd ed). Upper Saddle River, NJ: Merrill/Prentice Hall.

Irving, J.A., \& Williams, D.I. (1995). Experience of group work in counselor training and preferred learning styles. Counselling Psychology Quarterly, 8, 139-144.

Jacobs, E., Masson, B., \& Harvill, R. (2002). Group counseling strategies and skills (4th ed.) Pacific Grove, CA: Brooks/Cole.

Johnson, P.W., \& Johnson, F.P. (1997). Joining together: Group theory and group skills. Needham Heights, MA: Allyn \& Bacon.

McGuire, J.M., Taylor, D.R., Broome, D.H., Blau, B.I., \& Abbott, D.W. (1986). Group structuring techniques and their influence on process involvement in a group counseling training group. Journal of Counseling Psychology, 33(3), 270-275

Merta, R., Wolfgang, L., \& McNeil, K. (1993). Five methods for using the experiential group in preparation of group counselors. Journal for Specialists in Group Work, 18, 200-207.

Osborn, C., Danninhirsch, C., \& Page, B. (2003). Experiential training in group counseling: Humanistic process in practice. Journal of Humanistic Counseling, Education, and Development, 42, 14-28.

Perrone, K. M., Smith, C.L., \& Carlson, T.E. (2003). Goal setting and attainment in graduate student training groups. College Student Journal, 37 (3), 456-461.

Robison, F., Jones, E., \& Berglund, K. (1996). Research on preparation of group leaders. Journal for Specialists in Group Work, 21 (3), 172-177.

Stockton, R., Morran, D.K., \& Harris, M. (1991). Factors influencing group member acceptance of corrective feedback. Journal for Specialists in Group Work, 16 (4), 246-254.

Yalom, I.D. (1995). The theory and practice of group psychotherapy (4th ed.). New York: Basic Books. 


\section{Appendix}

\section{TABLE 1}

\section{Correlations between Pre-group Process and Post-group Outcomes}

\begin{tabular}{|c|c|c|c|c|c|}
\hline Items & $\begin{array}{l}\text { Felt pressure to } \\
\text { bring up personal } \\
\text { issues }\end{array}$ & $\begin{array}{l}\text { Became less } \\
\text { nervous about } \\
\text { personal issues }\end{array}$ & $\begin{array}{l}\text { Concerned } \\
\text { about being } \\
\text { evaluated }\end{array}$ & $\begin{array}{l}\text { Knew how much } \\
\text { personal info to } \\
\text { disclose }\end{array}$ & $\begin{array}{l}\text { Difficult to stick } \\
\text { to relevant issues }\end{array}$ \\
\hline 1. Ready to trust in group & .15 & .03 & -.15 & .13 & .15 \\
\hline 2. Group trust me & .08 & .11 & -.49 & $.60 *$ & .08 \\
\hline 3. Self disclosure & .06 & -.25 & -.16 & .44 & -.38 \\
\hline 4. Formulate goals & -.39 & .34 & -.48 & .37 & -.06 \\
\hline 5. Active participant & .11 & -.09 & -.29 & 27 & 11 \\
\hline 6. Express feelings & .12 & .29 & -.12 & .11 & -.11 \\
\hline 7. Listens to others & .08 & 28 & -.22 & .25 & .08 \\
\hline 8. Doesn't give in to group pressure & .11 & .27 & -.31 & 47 & -.31 \\
\hline 9. Gives and receives feedback & -.03 & -.15 & .34 & $-.72 * *$ & -.03 \\
\hline 10. Thinks about achieving goals & -.20 & .18 & -.39 & .31 & .35 \\
\hline 11. Avoids monopolizing time & .06 & .34 & -.16 & 44 & .06 \\
\hline 12. Avoids storytelling & .30 & .34 & -.11 & $.56 *$ & .05 \\
\hline $\begin{array}{l}\text { 13. Avoids questioning and makes } \\
\text { direct statements }\end{array}$ & -.28 & .43 & -.38 & .12 & .14 \\
\hline 14. Avoids giving pseudo-support & -.11 & .24 & -.15 & .48 & -.11 \\
\hline 15. Able to confront others & .50 & -.05 & .14 & .05 & -.38 \\
\hline
\end{tabular}

$* \mathrm{p}<.05 . \quad * * \mathrm{p}<.01$.

TABLE 2

Correlations between Pre-group Process and Post-group Attitudes

\begin{tabular}{lccccc}
\hline Items & $\begin{array}{l}\text { Choice in } \\
\text { participating }\end{array}$ & $\begin{array}{l}\text { Group violated } \\
\text { personal } \\
\text { boundaries }\end{array}$ & $\begin{array}{l}\text { Reservations } \\
\text { about } \\
\text { participating }\end{array}$ & $\begin{array}{l}\text { Uncomfortable } \\
\text { in group }\end{array}$ & $\begin{array}{l}\text { Upset about } \\
\text { participating }\end{array}$ \\
\hline 1. Ready to trust in group & .21 & .10 & .18 & .15 & .10 \\
2. Group trust me & .03 & .33 & .00 & -.32 & .33 \\
3. Self disclosure & .21 & .04 & .29 & -.38 & .04 \\
4. Formulate goals & .11 & .18 & -.16 & -.38 & .18 \\
5. Active participant & -.12 & .07 & -.26 & .11 & .07 \\
6. Express feelings & -.08 & .08 & -.15 & -.18 & .08 \\
7. Listens to others & .37 & -.22 & .00 & -.32 & -.22 \\
8. Doesn't give into group pressure & -.04 & .37 & .24 & -.31 & .37 \\
9. Gives and receives feedback & -.18 & -.29 & -.32 & .37 & -.29 \\
10. Thinks about achieving goals & .38 & .05 & -.18 & .07 & .05 \\
11. Avoids monopolizing time & .40 & -.26 & .40 & -.38 & .34 \\
12. Avoids storytelling & $.56 *$ & -.03 & .28 & -.05 & -.03 \\
13. Avoids questioning and makes & .06 & -.19 & -.34 & -.28 & .38 \\
direct statements & & & & & \\
14. Avoids giving pseudo-support & .09 & .15 & .43 & -.44 & .15 \\
15. Able to confront others & -.16 & .04 & .07 & .06 & .04 \\
\hline
\end{tabular}

$* \mathrm{p}<.05$ 


\section{Appendix}

\section{TABLE 3}

\section{Pre- and Post- Group Participants' Responses for Process, Outcomes and Attitudes}

\begin{tabular}{|c|c|c|c|}
\hline \multirow[t]{3}{*}{ Items } & \multicolumn{3}{|c|}{ Percentages } \\
\hline & Strongly Disagree & $\overline{\text { Agree }}$ & Strongly Agree \\
\hline & Pre/post & Pre/post & Pre/post \\
\hline \multicolumn{4}{|l|}{ PROCESS } \\
\hline 1. Ready to trust group & $6.7 / 6.7$ & $66.7 / 40.0$ & $26.7 / 53.3$ \\
\hline 2. Group trusts me & $0.0 / 0.0$ & $40.0 / 33.3$ & $60.0 / 66.7$ \\
\hline 3. Self disclosure & $6.7 / 0.0$ & $80.0 / 46.7$ & $13.3 / 53.3$ \\
\hline 4. Formulates goals & $6.7 / 0.0$ & $46.7 / 20.0$ & $46.7 / 80.0$ \\
\hline 5. Active participant & $6.7 / 0.0$ & $73.3 / 46.7$ & $20.0 / 53.3$ \\
\hline 6. Express feelings & $6.7 / 0.0$ & $73.3 / 46.7$ & $20.0 / 53.3$ \\
\hline 7. Listens to others and understands & $0.0 / 0.0$ & $40.0 / 33.3$ & $60.0 / 66.7$ \\
\hline 8. Doesn't give in to pressure & $33.3 / 6.7$ & $6.7 / 26.7$ & $60.0 / 66.7$ \\
\hline 9. Give/receive feedback & $0.0 / 0.0$ & $53.3 / 40.0$ & $46.7 / 60.0$ \\
\hline 10. Thinks about achieving goals & $20.0 / 6.7$ & $46.7 / 46.7$ & $33.3 / 46.7$ \\
\hline 11. Avoids monopolizing & $33.3 / 6.7$ & $20.0 / 20.0$ & $46.7 / 73.3$ \\
\hline 12. Avoids storytelling & 20.0/13.3 & $66.7 / 26.7$ & $13.3 / 60.0$ \\
\hline 13. Avoids questioning/makes direct statements & $6.7 / 0.0$ & $66.7 / 66.7$ & $0.0 / 26.7$ \\
\hline 14. Avoids giving pseudo-support & $6.7 / 0.0$ & $53.3 / 6.7$ & $40.0 / 93.3$ \\
\hline 15. Able to confront & $6.7 / 0.0$ & $13.3 / 73.3$ & $13.3 / 73.3$ \\
\hline \multicolumn{4}{|l|}{ OUTCOMES } \\
\hline 1. Felt pressure to disclose & $93.3 / 86.7$ & $6.7 / 13.3$ & $0.0 / 0.0$ \\
\hline 2. Nervous about disclosing & $40.0 / 46.7$ & $53.3 / 33.3$ & $6.7 / 20.0$ \\
\hline 3. Concerned about criticism & $60.0 / 53.3$ & $26.7 / 46.7$ & $13.3 / 0.0$ \\
\hline 4. Knew how much to disclose & $6.7 / 20.0$ & $53.3 / 33.3$ & $40.0 / 46.7$ \\
\hline 5. Difficult to stick to issues & $80.0 / 86.7$ & $20.0 / 13.3$ & $0.0 / 0.0$ \\
\hline \multicolumn{4}{|l|}{ ATTITUDES } \\
\hline 1. Felt like I had a choice & $40.0 / 40.0$ & $20.0 / 33.3$ & $40.0 / 26.7$ \\
\hline 2. Violated personal boundaries & $100.0 / 93.3$ & $0.0 / 6.7$ & $0.0 / 0.0$ \\
\hline 3. Had strong reservations & $73.3 / 80.0$ & $6.7 / 6.7$ & $20.0 / 13.3$ \\
\hline 4. Was uncomfortable & $86.7 / 86.7$ & $13.3 / 13.3$ & $.0 / 0.0$ \\
\hline 5. Upset about participating & $86.7 / 93.3$ & $13.3 / 6.7$ & $0.0 / 0.0$ \\
\hline
\end{tabular}




\section{Appendix}

\section{TABLE 4}

Group Process Pre-Post Test Means and Standard Deviations

\begin{tabular}{lll} 
Items & Pre/Post Test Means & Pre/Post Test SD \\
\hline 1. Ready to trust in group & $2.20 / 2.47$ & $.56 / .64$ \\
2. Group trusts me & $2.60 / 2.67$ & $.51 / .49$ \\
3. Self disclosure & $2.07 / 2.53$ & $.46 / .52$ \\
4. Formulate goals & $2.40 / 2.80$ & $.63 / .41$ \\
5. Active participant & $2.13 / 2.53$ & $.52 / .52$ \\
6. Express feelings & $2.20 / 2.60$ & $.68 / .51$ \\
7. Listens to others & $2.60 / 2.67$ & $.51 / .49$ \\
8. Doesn't give in to group pressure & $2.27 / 2.60$ & $.96 / .63$ \\
9. Gives/ receives feedback & $2.47 / 2.60$ & $.52 / .51$ \\
10. Thinks about achieving goals & $2.13 / 2.40$ & $.74 / .63$ \\
11. Avoids monopolizing time & $2.13 / 2.67$ & $.92 / .62$ \\
12. Avoids storytelling & $1.93 / 2.47$ & $.59 / .74$ \\
13. Avoids questioning \& makes direct statements & $1.67 / 2.20$ & $.49 / .56$ \\
14. Avoids giving pseudo-support & $2.33 / 2.93$ & $.62 / .26$ \\
15. Able to confront others & $2.07 / 2.73$ & $.46 / .46$ \\
\hline
\end{tabular}

TABLE 5

Wilcoxon Signed Rank Test Pre-Post Group Process Differences

\begin{tabular}{llc} 
Items & Z-value & $\mathrm{N}$ minus ties \\
\hline 1. Ready to trust in group & 1.75 & $9 *$ \\
2. Group trusts me & 1.41 & 6 \\
3. Self disclosure & 2.33 & $10^{*}$ \\
4. Formulate goals & 2.11 & $12^{*}$ \\
5. Active participant & 2.24 & $9 *$ \\
6. Express feelings & 2.45 & $10^{* *}$ \\
7. Listens to others & 1.41 & 6 \\
8. Doesn't give in to group pressure & 2.27 & $10^{*}$ \\
9. Gives/ receives feedback & 1.76 & $5 *$ \\
10. Thinks about achieving goals & 1.41 & 9 \\
11. Avoids monopolizing time & 2.07 & $9 *$ \\
12. Avoids storytelling & 2.31 & $13^{*}$ \\
13. Avoids questioning and makes & 2.53 & $11 * *$ \\
direct statements & & \\
14. Avoids giving pseudo-support & 2.71 & $12^{* *}$ \\
15. Able to confront others & 2.71 & $12^{* *}$ \\
\hline$* \mathrm{p} \leq .05$, one-tailed & $* * 01$, one-tailed
\end{tabular}

